\title{
Synthesis, Antioxidant and Cytotoxic Activities of Novel Naphthoquinone Derivatives from 2,3-Dihydro-2,3-Epoxy-1,4- Naphthoquinone
}

\author{
Berghot MA, Kandeel EM, Abdel-Rahman AH and Marwa Abdel-Motaal*
}

Department of Chemistry, Faculty of Science, Mansoura University, El-Gomhoria Street, Mansoura, 35516, Egypt

\begin{abstract}
A series of newly naphthoquinone derivatives were synthesized using 2,3- dihydro-2,3-epoxy-1,4-naphthoquinone (1) as a starting material. The corresponding acetophenyl derivative 7 was used as building blocks for synthesis of different heterocycles incorporated naphthoquinone moiety. The newly synthesized compounds were characterized utilizing the corresponding analytical and spectroscopic data and evaluated as antioxidant activity by superoxide (NBT) free radical scavenging methods. Compounds 21, 22 promosing the more potent antioxidant agents than ascorbic acid. Moreover, the newly synthesized quinones were tested for their Cytotoxicity by brine shrimp lethality bioassay. Quinone derivatives 3, 12, 18, 23 were proven to be the best potent cytotoxic agents.
\end{abstract}

Keywords: Hydroxynaphthoquinones; Acetophenone; Active methylene compounds; Antioxidant Activity and Brine shimp lethality bioassay

\section{Introduction}

Epoxides are versatile intermediates in organic synthesis and are well-known carbon electrophiles capable of reacting with variety of reagents such as, electrophiles, nucleophiles, acids, bases, reducing agents, and some oxidizing agents are widely studied [1].

Ring opening reactions of epoxynaphthoquinones with nucleophiles are considered as an interesting approach in organic synthes is of many functionalized oxygenated compounds. The reactions with nucleophiles such as oxygen compounds [2-6], nitrogen compounds [7,8], thiols [9-11] and various carbon nucleophiles [12,13] were performed in both organic and aqueous solvents. 2,3-Dihydro2,3-epoxy-1,4-naphthoquinones are important intermediates in the synthesis of several biologically active compounds [14-17]. However, their reactions with active methylene compounds are described for the first time. Further studies proved that the toxicity of naphthoquinones to Plasmodium sp. is due to interaction with the mitochondrial respiratory chain [18]. Since ring cleavage of epoxynaphthoquinones with active methylene compounds presents an effective synthetic route of hydroxynaphthoquinone derivatives. In addition, Naphthoquinones that have one or more hydroxy groups attached directly to the quinone moiety are found in nature in great variety $[19,20]$. Hydroxynaphthoquinones possess important anti-cancer [21] and anti- protozoal [22,23] agents: in particular, lapachol (1) and some of its analogues possess antitumor, antibiotic, anti-malarial, anti-inflammatory and anti-ulcer activities [24]. Recent results have also demonstrated strong trypanocidal $[25,26]$ and molluscicidal (against B. glabrata) activities [26-28]. Most of 2- hydroxy-3-alkylnaphthoquinones inhibited certain the growth of $\mathrm{P}$. Vivae upon the influence on the respiratory and carbohydrate cycles in the parasite [29]. Moreover, these compounds were submitted to molluscicidal bioassays against the snail Biomphalaria glabrata, intermediate host of Schistosoma mansoni [30].

Thus, several methods were reported for the synthesis of hydroxynaphthoquinone compounds $[31,32]$. In view of the above mentioned findings and in continuation of our work, we report herein the use of 2,3-dihydro-2,3- epoxy-1,4-naphthoquinone (4) [33,34] as a key starting material for the synthesis of various novel heterocycles incorporated 1,4-naphthoquinone moiety.

\section{Results and Discussion}

\section{Chemistry}

The synthetic strategies adopted to obtain the target compounds are depicted in Schemes 1-5. The starting 2,3-dihydro-2,3-epoxy1,4-naphthoquinone (1) reacted with active methylene compounds namely; malononitrile, ethyl cyanoacetate, diethyl malonate, ethyl acetoacetate and acetyl acetone in sodium ethoxide to afford 2-hydroxy3 -substituted-1,4-napthoquinone derivatives 2-6, respectively. Structures 2-6 were characterized by analytical and spectral data. The IR spectra showed absorption bands within $v 3446-3170 \mathrm{~cm}^{-1}$ corresponding to hydroxyl groups. The IR spectra of compounds 2 and 3 showed stretching absorption bands at $2208,2204 \mathrm{~cm}^{-1}$ duee to cyano functions, respectively. The ${ }^{1} \mathrm{H}-\mathrm{NMR}$ spectra of compounds $3-5$ revealed characteristic signals due to ester protons at $\delta 1.2\left(\mathrm{t}, 3 \mathrm{H}, \mathrm{CH}_{2}-\right.$ $\left.\mathrm{CH}_{3}\right)$ and $4.2 \mathrm{ppm}\left(\mathrm{q}, 2 \mathrm{H}, \mathrm{CH}_{2}-\mathrm{CH}_{3}\right)$ in addition to singlet signals at $\delta$ 2.2-5.6 ppm corresponding to methylene protons.

In a similar manner, treatment of 1 with acetophenone in sodium ethoxide furnished 2-hydroxy-3-(2-oxo-2-phenylethyl)naphthalene1,4-dione (7). Compound 7 was elucidated by analytical and spectral data. Its IR spectrum showed bands at $v 3343$ due to hydroxyl group and 1781,1671 and $1646 \mathrm{~cm}^{-1}$ corresponding to carbonyl group. In addition, the ${ }^{1} \mathrm{H}-\mathrm{NMR}$ spectrum revealed singlet signals at $\delta 6.1$ and $11.6 \mathrm{ppm}$ due to methylene and hydroxyl protons, respectively. The mass spectrum gave an additional evidence for the structure elucidation which showed the molecular ion peak at $m / z 292\left(\mathrm{M}^{+}\right)$(Scheme 1).

Subsequent reactions of the ethyl acetoacetate derivative 5 with phenyl hydrazine or hydrazine hydrate in ethanol containing a catalytic amount of acetic acid afforded the corresponding pyridazine

*Corresponding author: Marwa Abdel-Motaal, Department of Chemistry, Faculty of Science, Mansoura University, El-Gomhoria Street, Mansoura 35516, Egypt, Tel: +20168059390, +20502223852; Fax: '+20502246781 E-mail: dr_marwachem@mans.edu.eg

Received January 19, 2014; Accepted March 22, 2014; Published March 25 2014

Citation: Berghot MA, Kandeel EM, Abdel-Rahman AH, Abdel-Motaal M (2014) Synthesis, Antioxidant and Cytotoxic Activities of Novel Naphthoquinone Derivatives from 2,3-Dihydro-2,3-Epoxy-1,4- Naphthoquinone. Med chem 4: 381388. doi:10.4172/2161-0444.1000169

Copyright: (C) 2014 Berghot MA, et al. This is an open-access article distributed under the terms of the Creative Commons Attribution License, which permits unrestricted use, distribution, and reproduction in any medium, provided the original author and source are credited. 


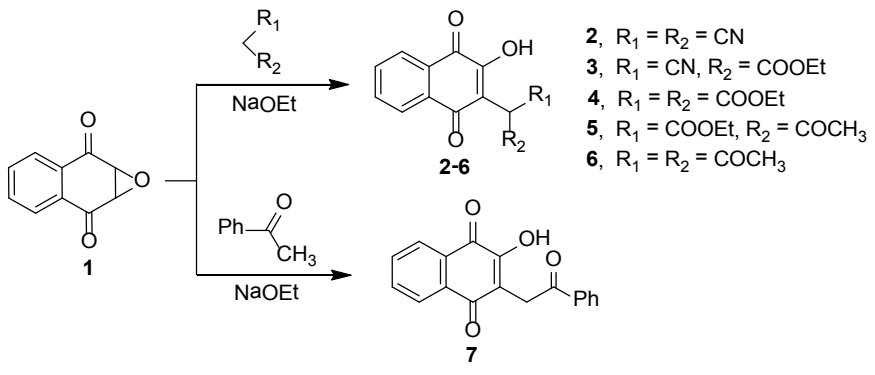

Scheme 1: Reactions of 2,3-epoxy-1,4-naphthoquinone 1 with active methylene compounds in basic medium.

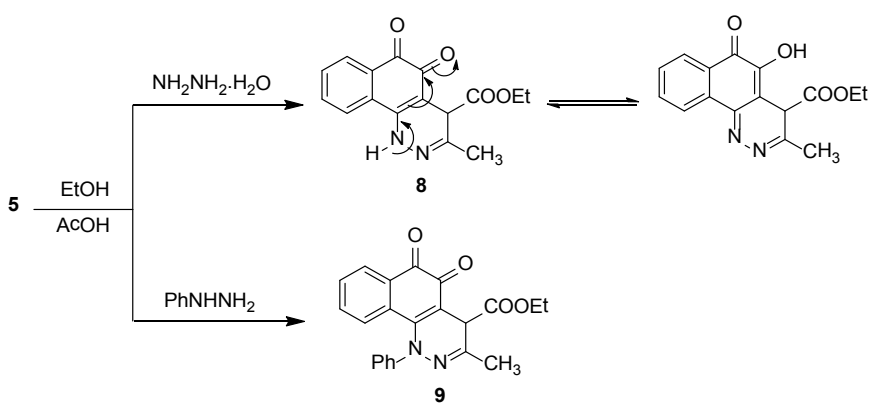

Scheme 2: Syntheses of pyridazine derivatives $\mathbf{8}$ and $\mathbf{9}$

derivatives 8 and 9 , respectively (Scheme 2). Assignment of products 8 and 9 were based on IR, ${ }^{1} \mathrm{H}-\mathrm{NMR},{ }^{13} \mathrm{C}-\mathrm{NMR}$ and mass spectra. The IR spectrum of 8 showed absorption bands at $v 3442,2972$ and 1670 $\mathrm{cm}^{-1}$ corresponding to $(\mathrm{OH}),(\mathrm{CH}$ aliphatic) and (CO ester) groups, respectively. The ${ }^{1} \mathrm{H}-\mathrm{NMR}$ spectrum of 8 displayed characteristic signals at $\delta 1.4\left(\mathrm{t}, 3 \mathrm{H}, \mathrm{CH}_{2}-\mathrm{CH}_{3}\right), 2.04\left(\mathrm{~s}, 3 \mathrm{H}, \mathrm{CH}_{3}\right), 2.4(\mathrm{~s}, 1 \mathrm{H}, \mathrm{CH})$, $4.2 \mathrm{ppm}\left(\mathrm{q}, 2 \mathrm{H}, \mathrm{CH}_{2}\right)$. On the other hand, the IR spectrum of 9 showed bands at $v 2975$ and $1738 \mathrm{~cm}^{-1}$ ( $\mathrm{CH}$ aliphatic) and $(\mathrm{C}=\mathrm{O})$, respectively. In addition, the ${ }^{1} \mathrm{H}-\mathrm{NMR}$ spectrum of 9 showed $\delta 1.4\left(\mathrm{t}, 3 \mathrm{H}, \mathrm{CH}_{2}-\mathrm{CH}_{3}\right)$, $2.5\left(\mathrm{~s}, 3 \mathrm{H}, \mathrm{CH}_{3}, 2.06(\mathrm{~s}, 1 \mathrm{H}, \mathrm{CH}), 4.3 \mathrm{ppm}\left(\mathrm{q}, 2 \mathrm{H}, \mathrm{CH}_{2}\right)\right.$. The mass spectra of compounds 8 and 9 showed the molecular ion peaks at $m / z 298\left(\mathrm{M}^{+}\right)$ and $374\left(\mathrm{M}^{+}\right)$, respectively which is in agreement with the molecular formula. The ${ }^{13} \mathrm{C}$-NMR spectra revealed signals at $\delta 16.2,18.0,31.4$, $66.5 \mathrm{ppm}$ due to ester and methyl carbons of compound 8 and 12.8, 18.4, 33.7, $65.0 \mathrm{ppm}$ due to ester methyl carbons of compound 9.

In order to extend the scope of this reaction and to increase the biological and synthetic importance of the formed products, compound 7 was used as a key intermediate for the construction of variety of heterocyclic compounds incorporated 2-hydroxy1,4-naphthoquinone nucleus as a structural unit. Thus, reaction of compound 7 with equimolar amounts of thiosemicarbazide or phenyl hydrazine in ethanol containing catalytic amounts of acetic acid afforded the corresponding thiosemicarbazone 10 and indole 11 derivatives, respectively. Attempts to cyclize compound 10 were failed. Structures 10 and 11 were established on the basis of analytical and spectral data. The ${ }^{1} \mathrm{H}-\mathrm{NMR}$ spectrum of 10 showed singlet signals at $\delta$ 2.3, 6.07, 9.1, 9.8 and $13.2 \mathrm{ppm}$ corresponding to $\mathrm{CH}_{2}, \mathrm{NH}, \mathrm{NH}_{2}$ and $\mathrm{OH}$, respectively. The ${ }^{13} \mathrm{C}-\mathrm{NMR}$ of compound 10 spectra revealed signals at $\delta 10.4 \mathrm{ppm}$ due to methylene carbons. Also, its mass spectrum showed the molecular ion peak at $365\left(\mathrm{M}^{+}, 6.39 \%\right)$. On the other hand, the ${ }^{1} \mathrm{H}$ - NMR spectrum of 11 revealed the absence of the singlet signal due to methylene protons and revealed singlet signals at $\delta 6.07$ and 16.1 ppm due to $\mathrm{NH}$ and $\mathrm{OH}$ protons, respectively. The mass spectrum of 11 showed the molecular ion peak at $m / z 366$ (M, 1.5\%).
The Gewald reaction of compound 7 with equimolar amounts of ethyl cyanoacetate and elemental sulfur in ethanol containing morpholine furnished the corresponding thiophene derivative 12 (Scheme 3). The IR spectrum of compound 12 exhibited absorption bands due to stretching vibrations of $\mathrm{OH},\left(\mathrm{NH}_{2}\right)$ and (CO ester) groups at $v 3478,3373$ and $1675 \mathrm{~cm}^{-1}$, respectively. Also, it's ${ }^{1} \mathrm{H}$ NMR spectrum showed a triplet signal at $\delta 1.2 \mathrm{ppm}$ and a quartet signal at $\delta$ 4.1 corresponding to ethyl ester protons, beside singlet signal of $\mathrm{NH}_{2}$ protons at $\delta 12.1 \mathrm{ppm}$. Its ${ }^{13} \mathrm{C}$-NMR spectrum revealed signals at $\delta 15.0$, $19.5,52.3 \mathrm{ppm}$ due to ester carbons. The mass spectrum of 12 showed the molecular ion peak at $m / z=418\left(\mathrm{M}^{+}-1,55.7 \%\right)$.

Cyclization of compound 7 in boiling acetic acid yielded naphthofuran derivative 13 in good yield. On the other hand, compound 13 was efficiently achieved with an alternative route. Thus, it has been found that stirring of 1,4- naphthoquinone 15 with phenacylpyridinium iodide 14 in acetonitrile containing a catalytic amount of triethylamine afforded a product similar in all respects (IR, m.p., ${ }^{1} \mathrm{H}-\mathrm{NMR}$ and mass spectra) to compound 13 (Scheme 3). Structure 13 was confirmed on the basis of analytical and spectral data. The IR spectrum lacked the absorption bands of $(\mathrm{OH})$ and $\left(\mathrm{CH}_{2} \mathrm{CO}\right)$ and exhibited absorption bands at $v 3055$ (CH, aromatic), 1675, 1639 $(\mathrm{C}=\mathrm{O})$, respectively. Moreover, the ${ }^{1} \mathrm{H}-\mathrm{NMR}$ spectrum of 13 revealed the absence of singlet signals of methylene and hydroxy protons, in addition, aromatic protons appeared as multiplet signals at $\delta$ 7.4-8.1 ppm. The mass spectrum showed the molecular ion peak at $\mathrm{m} / z 274$ $\left(\mathrm{M}^{+}\right)$which is in agreement with the molecular formula $\left(\mathrm{C}_{18} \mathrm{H}_{10} \mathrm{O}_{3}\right)$.

In addition, subsequent Vilsmeier-Haack formylation and coupling reactions for compound 13 afforded the corresponding 3-formyl and 3-arylazo 16 and 17 derivatives, respectively (Scheme 3). Structures 16 and 17 were supported by analytical and spectral data. The IR spectrum of 16 exhibited absorption bands due to stretching vibrations of $(\mathrm{CHO})$ and $(\mathrm{C}=\mathrm{O})$ at $3056,1643,1622 \mathrm{~cm}^{-1}$, respectively. Furthermore, the ${ }^{1} \mathrm{H}-\mathrm{NMR}$ spectrum of 16 displayed singlet signal at $\delta 9.4 \mathrm{ppm}$ corresponding to aldehydic proton. Moreover, its mass spectrum showed the molecular ion peak at $m / z 300\left(\mathrm{M}^{+}-2,13 \%\right)$. On the other hand, the IR spectrum of 17 exhibited absorption bands due to stretching vibrations of $(\mathrm{C}=\mathrm{O})$ and for $(\mathrm{N}=\mathrm{N})$ groups at 1666,1592 and $1549 \mathrm{~cm}^{-1}$, respectively. The mass spectrum showed the molecular ion peak at $m / z 425\left(\mathrm{M}^{+}+2\right)$.

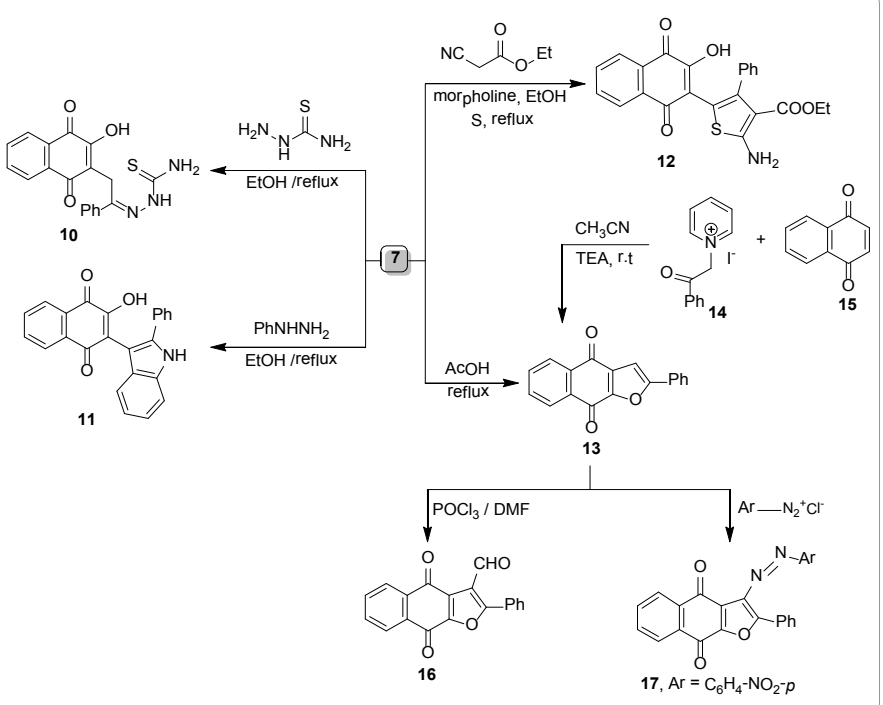

Scheme 3: Synthesis of thiosemicarbazone, indole, thiophene and naphthofuran derivatives. 
Reaction of 7 with 1-(2-oxo-2-phenylethyl)pyridin-1-ium iodide (14) and $p$-chlorobenzaldehyde in acetic acid containing ammonium acetate gave pyridine derivative 18 in high yield, similar behavior has been reported $[35,36]$. Structure 18 was characterized by IR, ${ }^{1} \mathrm{H}-\mathrm{NMR}$, ${ }^{13} \mathrm{C}-\mathrm{NMR}$ and mass spectral data. The ${ }^{1} \mathrm{H}-\mathrm{NMR}$ spectrum revealed the absence of the singlet signal due to methylene protons and showed multiplet signals due to aromatic protons at $\delta 7.2-8.4 \mathrm{ppm}$. Moreover, its ${ }^{13} \mathrm{C}$-NMR revealed signals the absence of the methylene carbon and all of signals in the aromatic region. Its mass spectrum showed the molecular ion peak at $m / z 516\left(\mathrm{M}^{+}+2\right)$. The formation of compound 18 was explained according to the plausible mechanism outlined in Scheme 4, similar cyclization has been reported [37].

Condensation of 7 with arylidinemalononitrile (19) in ethanol containing a catalytic amount of triethylamine afforded 2-amino-5-(3-hydroxy-1,4-dioxo-1,4-dihydronaphthalen-2-yl)4-(4-methoxyphenyl)-6-phenyl-4H-pyran-3-carbonitrile(20) and 2-(2-(3-hydroxy-1,4-dioxo-1,4-dihydronaphthalen-2-yl)-1-(4methoxyphenyl)-3-oxo-3-phenylpropyl)malononitrile (21). This reaction occurred via Michael addition of compound 7 to the electron deficient arylidenemalononytrile 19 followed by intramolecular cyclization. The intermediate 21 was isolated from the reaction. Structures 20 and 21 were ascertained by their analytical and spectral data. The IR spectrum of 20 showed bands at 3403,3220 for $\mathrm{OH},\left(\mathrm{NH}_{2}\right)$, 2927 ( $\mathrm{CH}$ aliphatic), $2220(\mathrm{CN})$. Furthermore, the ${ }^{1} \mathrm{H}-\mathrm{NMR}$ spectrum of compound 20 displayed singlet signals at $\delta 3.6,3.8$ and $4.5 \mathrm{ppm}$ for $\left(\mathrm{CH}_{3}\right),(\mathrm{CH})$ and $\left(\mathrm{NH}_{2}\right)$, respectively. The IR spectrum of 21 showed bands at $3340(\mathrm{OH}), 2931$ (CH aliphatic), $2210(\mathrm{CN})$. Its ${ }^{1} \mathrm{H}-\mathrm{NMR}$ spectrum revealed signals at $\delta 2.9(\mathrm{~d}, 1 \mathrm{H}, \mathrm{CH}-\mathrm{CN}), 3.7\left(\mathrm{~s}, 3 \mathrm{H}, \mathrm{OCH}_{3}\right)$, $6.1(\mathrm{~s}, 1 \mathrm{H}, \mathrm{OH}), 4.6$ (d, 1H, CHCO), 3.9 (t, 1H, CH-Ar), 6.7-8.0 ppm $(\mathrm{m}, 13 \mathrm{H}, \mathrm{Ar}-\mathrm{H})$. Their mass spectra showed molecular ion peaks at $m / z$ $476\left(\mathrm{M}^{+}\right)$and $476\left(\mathrm{M}^{+}\right)$, respectively which were equivalent with their molecular formula.

A one pot condensation reaction of 7 with $p$-substituted benzaldehydes and 2-aminobenzothiazol in boiling DMF for a short time $(10-15 \mathrm{~min})$ resulted in the formation of the compound 22 in good yield. A reasonable mechanism for the formation of compound 23 is outlined in Scheme 5 via formation of the intermediate 22 .

A confirmation for this proposed mechanism by synthesis of the intermediate 22 as Schiff base and subsequently reacted with 7 under the same conditions, the expected product 23 was obtained in a yield

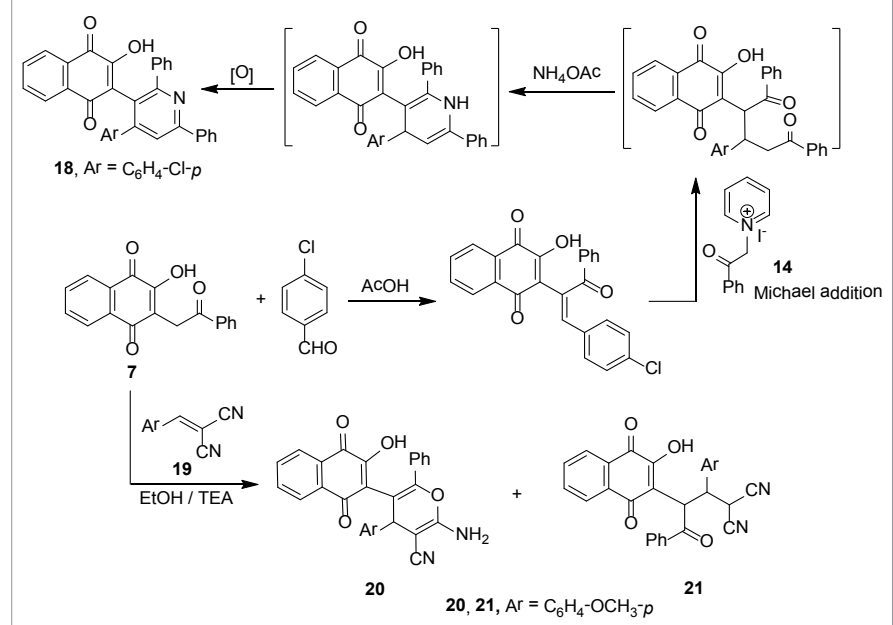

Scheme 4: Synthesis of pyridine and $4 H$-pyran derivatives 18 and 20.

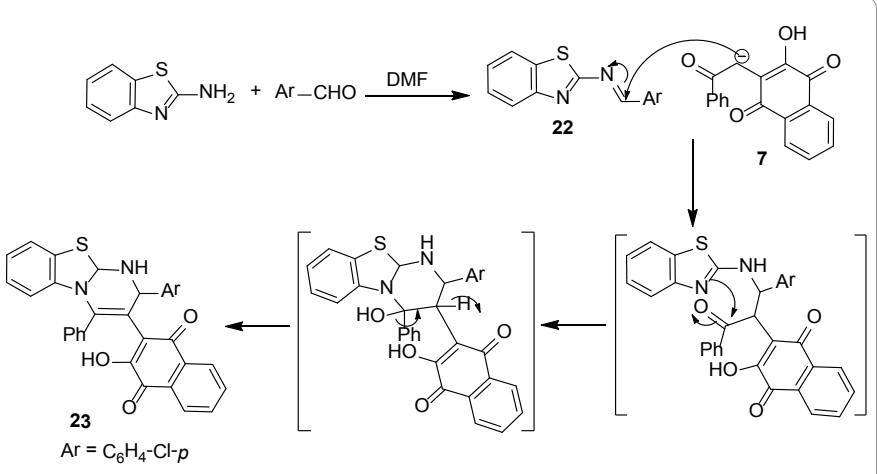

Scheme 5: Synthesis of thiazolopyrimidine derivative 23.

similar to that obtained in a one-pot reaction. Structure 23 was assessed by analytical and spectral data. Its IR spectrum revealed the absence of the band due to a carbonyl group and showed absorption frequencies at 3442 and $3417 \mathrm{~cm}^{-1}$ due to $\mathrm{OH}$ and $\mathrm{NH}$ groups, respectively. The ${ }^{1} \mathrm{H}-\mathrm{NMR}$ spectrum displayed characteristic signals at $\delta 2.7(\mathrm{~s}, 1 \mathrm{H}, \mathrm{CH})$, $2.9\left(\mathrm{~s},{ }^{1} \mathrm{H}, \mathrm{CHS}\right), 5.2(\mathrm{~s}, 1 \mathrm{H}, \mathrm{NH})$ and $6.8 \mathrm{ppm}(\mathrm{s}, 1 \mathrm{H}, \mathrm{OH})$, in addition to the expected signals for the other protons. The ${ }^{13} \mathrm{C}$-NMR spectrum revealed the presence of signals of the aliphatic carbon at $\delta 68.4$ and 54.8 p.m. in addition to the other expected signals. Furthermore, its mass spectrum showed the molecular ion peak at $m / z 546\left(\mathrm{M}^{+}-2,26 \%\right)$ which is in agreement with the molecular formula $\left(\mathrm{C}_{43} \mathrm{H}_{23} \mathrm{~N}_{3} \mathrm{O}_{9}\right)$.

\section{Biological evaluation}

Antioxidant activity: The newly synthesized compounds were screened for their antioxidant activity by measuring their scavenging effects on the superoxide radical scavenging using nitroblue tetrazolium chloride (NBT) assay as reported $[38,39]$. The scavenging activities of the tested compounds were measured at a dose level of $1000 \mu \mathrm{g} / \mathrm{ml}$ and ascorbic acid was used as standard for antioxidant activity.

From the superoxide scavenging activity data (Table 1), the investigation of antioxidant screening revealed that most of the tested compounds showed moderate to good antioxidant activity. It would appear generally that Compounds containing $\mathrm{OH}$ groups attached to quinone moiety exhibited higher antioxidant activity as compared to standard, ascorbic acid. As a result compounds 21, 23 exhibited more potently scavenging antioxidant activity higher than ascorbic acid. In addition the data showed clearly that compounds $2,3,11,18$ and 20 good activities, while compounds 10 and 6 exhibited moderate activities. On the other hand, the rest of compounds exhibited weak activities.

By comparing the results obtained of the investigated compounds to their structures the following structure activity relationships (SAR's) were postulated:

1. The higher activities of naphthoquinones 21 and 23 may be attributed to the presence of two cyano groups for compound 21 (so 22 less activity than 21) and the presence of the thiazole moiety for 23 .

2. Naphthoquinones 2 and 3 more potent than their analog derivatives 4, 5, 6 and 7 may be due to the presence of cyano groups.

3. Presence of heterocycles such as pyridine and insole could significantly increase the antioxidant Activity. So, compounds 11 and 18 show potent antioxidative properties. 
4. The low action is most probably due to the disabling of these compounds to catch radicals (Table 1).

Brine shrimp lethality test: The brine shrimp eggs (Artemia salina) were hatched in artificial sea water and used after $48 \mathrm{~h}$, providing large numbers of larvae. These tiny shrimp larvae have been extensively used as a tool to monitor the cytotoxicity of samples under study. This is a rabid, inexpensive and general bioassay which has been developed for screening. It easily utilizes a large number of organisms for statistical validation and requires no special equipment and a relatively small amount of sample is sufficient. Furthermore, it does not require animal serum, as it is needed for determination of cytotoxicity.

From Table 2, most of the newly synthesized tested compounds showed potent cytotoxic activities against Brine shrimp (Artemia salina) lethality assay. Compound 3 exhibited the higher activity in the brine shrimp assay for overall toxicity profile, this may be due the presence of hydroxyl and cyano groups. It has been observed that quinone derivatives $12,18,23$ in respective series exhibited high cytotoxic activity this is may be due to the presence of thiophene, pyridine and thiazole moieties attached to the naphthoquinone ring system. Moreover, compounds 4, 5, 6, 11 and 20 exhibited moderate cytotoxic activities. In addition Table 2 show that the cytotoxic activities increase as the doses increase, therefore the $1000 \mu \mathrm{g} / \mathrm{mL}$ doses induced more cell death than the $100 \mu \mathrm{g} / \mathrm{mL}$ doses and these doses induced more cell death than $10 \mu \mathrm{g} / \mathrm{ml}$ doses.

\section{Experimental}

\section{Instruments}

All melting points are recorded in Gallenkamp electric melting point apparatus and are uncorrected. The IR spectra $v\left(\mathrm{~cm}^{-1}\right)(\mathrm{KBr})$ were recorded on a Perkin Elmer Infrared Spectrophotometer Model 157 at the Microanalytical unit, Mansoura University, Faculty of Science. The ${ }^{1} \mathrm{H}-\mathrm{NMR}$ and ${ }^{13} \mathrm{C}-\mathrm{NMR}$ spectra were recorded on a Varian 300 and $75 \mathrm{MHz}$ spectrometer using the indicated solvents using tetramethylsilane (TMS) as an internal reference and dimethylsulfoxide (DMSO) as solvent (Microanalytical Center, Faculty of Science, Cairo University, Egypt). The mass spectra (EI) were recorded on $70 \mathrm{eV}$ with Kratos MS equipment at the Microanalytical Center, Faculty of

\begin{tabular}{|c|c|c|}
\hline Entry & Compound No. & Inhibition \% \\
\hline 1 & Vit. C & 71.3 \\
\hline 2 & 2 & 79.3 \\
\hline 3 & 3 & 39 \\
\hline 4 & 4 & 52 \\
\hline 5 & 5 & 77.5 \\
\hline 6 & 6 & 66.5 \\
\hline 7 & 7 & 51.0 \\
\hline 8 & 8 & 55.2 \\
\hline 9 & 9 & 47.1 \\
\hline 10 & 10 & 76 \\
\hline 11 & 11 & 79.6 \\
\hline 12 & 12 & 51 \\
\hline 13 & 13 & 22 \\
\hline 14 & 16 & 26.3 \\
\hline 15 & 17 & 15.6 \\
\hline 16 & 18 & 79 \\
\hline 17 & 20 & 77.1 \\
\hline 18 & 21 & 82.8 \\
\hline 19 & 22 & 80.5 \\
\hline
\end{tabular}

Table 1: Free radical scavenging capacities of naphthoquinone derivatives 2-22 measured in NBT assay at a dose $1000 \mu \mathrm{g} / \mathrm{mL}$.

\begin{tabular}{|c|c|c|c|}
\hline \multirow{2}{*}{ Compound No. } & \multicolumn{3}{|c|}{ Dead mean $\%$} \\
\cline { 2 - 4 } & $\mathbf{1 0 0 0} \mathbf{~ g / m L}$ & $\mathbf{1 0 0} \mathbf{\mu g} / \mathbf{m L}$ & $\mathbf{1 0} \mathbf{~ g / m L}$ \\
\hline $\mathbf{2}$ & 12.5 & 7.7 & 4.5 \\
\hline $\mathbf{3}$ & 94.1 & 50.0 & 7.1 \\
\hline $\mathbf{4}$ & 73.0 & 41.4 & 9.5 \\
\hline $\mathbf{5}$ & 55.0 & 30.0 & 13.0 \\
\hline $\mathbf{6}$ & 46.0 & 16.7 & 6.8 \\
\hline $\mathbf{7}$ & 14.3 & 13.3 & 8.0 \\
\hline $\mathbf{8}$ & 15.7 & 8.0 & 1.4 \\
\hline $\mathbf{9}$ & 7.7 & 5.4 & 0 \\
\hline $\mathbf{1 0}$ & 54.0 & 12.5 & 9.5 \\
\hline $\mathbf{1 1}$ & 65.9 & 25.5 & 11.6 \\
\hline $\mathbf{1 2}$ & 87.3 & 66.1 & 28.0 \\
\hline $\mathbf{1 3}$ & 18.2 & 13.9 & 10.7 \\
\hline $\mathbf{1 8}$ & 89.0 & 42.1 & 20.0 \\
\hline $\mathbf{2 0}$ & 69.1 & 18.3 & 4.5 \\
\hline $\mathbf{2 1}$ & 12.0 & 10.1 & 5.2 \\
\hline $\mathbf{2 2}$ & 81.0 & 52.3 & 25.2 \\
\hline
\end{tabular}

Table 2: Brine shimp lethality assay for the investigated compounds.

Science, Cairo University, Egypt. Elemental analyses (C, H, and N) were carried out at the Microanalytical Center, Cairo University, Giza, Egypt. 2,3-Dihydro- 2,3-epoxy-1,4-naphthoquinone (1) was prepared according to the previously reported methods $[26,27]$.

Reaction of 2,3-dihydro-2,3-epoxy-1,4-naphthoquinone (1) with active methylene compounds:

General procedure: To a solution of active methylene compounds namely; malononitrile, ethyl cyanoacetate, diethyl malonate, ethyl acetoacetate, acetylacetone or acetophenone $(5 \mathrm{mmol})$ in sodium ethoxide [prepared from sodium metal $(0.23 \mathrm{~g}, 10 \mathrm{mmol})$ in absolute ethanol $(15 \mathrm{~mL})$ ] was heated over steam path for $15 \mathrm{~min}$ and then a solution of $1(5 \mathrm{mmol})$ in ethanol $(10 \mathrm{~mL})$ was added. The reaction mixture was stirred at room temperature for further $1 \mathrm{~h}$. The solvent was evaporated in vacuum and the residue was diluted with $\mathrm{H} 2 \mathrm{O}$, washed with diethyl ether and the aqueous layer was acidified with $10 \%$ $\mathrm{HCl}$ at $0^{\circ} \mathrm{C}$ to afford 2-hydroxy-1,4-naphthoquinone derivatives 2-7, respectively.

2-(3-Hydroxy-1,4-dioxo-1,4-dihydronaphthalen-2-yl) malononitrile (2): Yield (45\%); black crystals; m.p. above $300^{\circ} \mathrm{C}$; IR (KBr): $v / \mathrm{cm}^{-1}=3174(\mathrm{OH}), 2208(\mathrm{CN}), 1637,1587(2 \mathrm{C}=\mathrm{O}) ;{ }^{1} \mathrm{H}-\mathrm{NMR}$ $(300 \mathrm{MHz}, \mathrm{DMSO}-d 6) \delta(\mathrm{ppm})=4.09(\mathrm{~s}, 1 \mathrm{H}, \mathrm{CH}), 7.1-8.2(\mathrm{~m}, 4 \mathrm{H}$, Ar-H), 9.4(s, $1 \mathrm{H}, \mathrm{OH}) ;{ }^{13} \mathrm{C}-\mathrm{NMR}\left(75 \mathrm{MHz}, \mathrm{DMSO}-d_{6}\right) \delta(\mathrm{ppm})=179$, 177.3, 144.2, 135.1, 120.4, 142.1, 152, 111.2, 95, 21.2; MS (EI, 70 ev) $\mathrm{m} / \mathrm{z}$ $(\%)=237\left(\mathrm{M}^{+}-1,2.5\right), 221(9), 194(31), 187$ (26), 146 (50), $132(27), 104$ (32). Anal. Calcd for $\mathrm{C}_{13} \mathrm{H}_{6} \mathrm{~N}_{2} \mathrm{O}_{3}(238.23)$ : $\mathrm{C}, 65.55 ; \mathrm{H}, 2.51 ; \mathrm{N}, 11.66 ; \mathrm{O}$, 20.1\%. Found: C, 65.32; H, 2.56; N, 11.53; O, 20.21\%.

Ethyl 2-cyano-2-(3-hydroxy-1,4-dioxo-1,4-dihydronaphthalen-2- yl)acetate (3): Yield (56\%); brown crystals; m.p. $>300^{\circ} \mathrm{C}$; IR $(\mathrm{KBr}): v / \mathrm{cm}^{-1}=3423(\mathrm{OH}), 2923(\mathrm{CH}$, aliphatic), $2204(\mathrm{CN}), 1641,1590$ $(\mathrm{C}=\mathrm{O}) ;{ }^{1} \mathrm{H}-\mathrm{NMR}(300 \mathrm{MHz}, \mathrm{DMSO}-d) \delta(\mathrm{ppm})=1.2\left(\mathrm{t}, 3 \mathrm{H}, \mathrm{CH}_{-}-\right.$ $\left.\mathrm{CH}_{3}\right), 4.2\left(\mathrm{q}, 2 \mathrm{H}, \mathrm{CH}_{2}\right), 5.1(\mathrm{~s}, 1 \mathrm{H}, \mathrm{CH}), 7.5-8.8(\mathrm{~m}, 5 \mathrm{H}, \mathrm{OH}, \mathrm{Ar}-\mathrm{H})$; ${ }^{13} \mathrm{C}$-NMR (75 MHz, DMSO-d6) $\delta(\mathrm{ppm})=188.0,183.1,178.2,175.5$, $160.1,152.2,132.1,136.3,122,120.1,118.3,112,80.1,38.8,19.7 ; \mathrm{MS}$ (EI, 70 ev) $m / z(\%)=285\left(\mathrm{M}^{+}, 66\right) ; 211$ (44), 157 (19), 172 (35), 132 (31), 112 (75), 104 (100.0). Anal. Calcd. for C15H11NO5 (285.03): C, 63.16; H, 3.89; N, 4.91; O, 28.12\%. Found: C, 63.22; H, 3.81; N, 4.98; $\mathrm{O}, 28.08 \%$.

Diethyl 2-(3-hydroxy-1,4-dioxo-1,4-dihydronaphthalen-2-yl) malonate (4): Yield (65\%); brown crystals; m.p. above $300^{\circ} \mathrm{C}$; $\mathrm{IR}(\mathrm{KBr})$ : 
$v / \mathrm{cm}^{-1}=3446(\mathrm{OH}), 2923\left(\mathrm{CH}\right.$, aliphatic), 1675, $1641(\mathrm{C}=\mathrm{O}) ;{ }^{1} \mathrm{H}-\mathrm{NMR}$ $\left(300 \mathrm{MHz}, \mathrm{DMSO}-d_{6}\right) \delta(\mathrm{ppm})=1.2\left(\mathrm{t}, 3 \mathrm{H}, \mathrm{CH}_{2}-\mathrm{CH}_{3}\right), 1.4\left(\mathrm{t}, 3 \mathrm{H}, \mathrm{CH}_{2}-\right.$ $\left.\mathrm{CH}_{3}\right), 5.6(\mathrm{~s}, 1 \mathrm{H}, \mathrm{CH}), 4.2\left(\mathrm{q}, 2 \mathrm{H}, \mathrm{CH}_{2}\right), 4.6\left(\mathrm{q}, 2 \mathrm{H}, \mathrm{CH}_{2}\right), 7.8-8.4(\mathrm{~m}$, $4 \mathrm{H}, \mathrm{Ar}-\mathrm{H}), 10.6(\mathrm{~s}, 1 \mathrm{H}, \mathrm{OH}) ;{ }^{13} \mathrm{C}-\mathrm{NMR}\left(75 \mathrm{MHz}, \mathrm{DMSO}-d_{6}\right) \delta(\mathrm{ppm})$ $=188.5,182,178.9,177.1,173.7,161.1,152.2,155.5,151,142,140.2$, $73.1,72.9,31.5,14.5,14.0$; MS (EI, 70 ev) $\mathrm{m} / z(\%)=322\left(\mathrm{M}^{+}, 92\right), 315$ (85), 173 (11), 105 (28), 76 (100.0). Anal. Calcd for $\mathrm{C}_{17} \mathrm{H}_{16} \mathrm{O}_{7}$ (322.3): C, 61.44; $\mathrm{H}, 4.85 ; \mathrm{O}, 33.71 \%$. Found: C, 61.32; H, 4.89; O, 33.64\%.

Ethyl 2-(3-hydroxy-1,4-dioxo-1,4-dihydronaphthalen-2-yl)-3oxobutanoate (5): Yield (77\%); bale yellow crystals; m.p. 186-7 C; IR (KBr): $v / \mathrm{cm}^{-1}=3170(\mathrm{OH}, \mathrm{H}-$ bond $), 1675,1644(\mathrm{C}=\mathrm{O}) ;{ }^{1} \mathrm{H}-\mathrm{NMR}(300$ $\left.\mathrm{MHz}, \mathrm{DMSO}-d_{6}\right) \delta(\mathrm{ppm})=1.2\left(\mathrm{t}, 3 \mathrm{H}, \mathrm{CH}_{2}-\mathrm{CH}_{3}\right), 2.08\left(\mathrm{~s}, 3 \mathrm{H}, \mathrm{COCH}_{3}\right)$, $2.2(\mathrm{~s}, 1 \mathrm{H}, \mathrm{CH}), 4.2\left(\mathrm{q}, 2 \mathrm{H}, \mathrm{CH}_{2}\right), 7.5-7.8(\mathrm{~m}, 12 \mathrm{H}, \mathrm{Ar}-\mathrm{H}) ;{ }^{13} \mathrm{C}-\mathrm{NMR}$ $\left(75 \mathrm{MHz}, \mathrm{DMSO}-d_{6}\right) \delta(\mathrm{ppm})=186-173(\mathrm{~m}), 151.5,142.8,138.8,135.7$, 58.9, 50.1, 29.2, 17.9; MS (EI, $70 \mathrm{ev}) \mathrm{m} / z(\%)=319\left(\mathrm{M}^{+}-1,2.5\right), 256(9)$, 132 (13), 129 (22), 104 (20). Anal. Calcd for $\mathrm{C}_{16} \mathrm{H}_{14} \mathrm{O}_{6}(302.26)$ : C, 63.57; H, 4.62; O, 31.75\%. Found: C, 63.50; H, 4.54; O, 31.79\%.

2-(2,4-Dioxopentan-3-yl)-3-hydroxynaphthalene-1,4-dione (6): Yield (79\%); yellow crystals; m.p. $160-1^{\circ} \mathrm{C}$; IR $(\mathrm{KBr}): v / \mathrm{cm}^{-1}=$ $3340(\mathrm{OH}), 1783,1677,1644(\mathrm{C}=\mathrm{O})$; ${ }^{1} \mathrm{H}-\mathrm{NMR}\left(300 \mathrm{MHz}, \mathrm{DMSO}-d_{6}\right)$ $\delta(\mathrm{ppm})=2.1\left(\mathrm{t}, 3 \mathrm{H}, \mathrm{COCH}_{3}\right), 2.2\left(\mathrm{~s}, 3 \mathrm{H}, \mathrm{COCH}_{3}\right), 3.4\left(\mathrm{~s},{ }^{1} \mathrm{H}, \mathrm{CH}\right)$, 7.2-7.9 (m, $4 \mathrm{H}, \mathrm{Ar}-\mathrm{H}), 8.5\left(\mathrm{~s},{ }^{1} \mathrm{H}, \mathrm{OH}\right) ;{ }^{13} \mathrm{C}-\mathrm{NMR}\left(75 \mathrm{MHz}, \mathrm{DMSO}-d_{6}\right)$ $\delta(\mathrm{ppm})=193.5,189.7,175.9,171.3,149.9,143.8,133.2,130.7,115.4$, 51.9, 25.8, 22.7; MS (EI, 70 ev) $m / z(\%)=272\left(\mathrm{M}^{+}, 21\right), 229(61), 245$ (18), 174 (100), 104 (17). Anal. Calcd. for $\mathrm{C}_{15} \mathrm{H}_{12} \mathrm{O}_{5}(272.25)$ : C, 66.17; H, 4.44; O, 29.38\%. Found: C, 66.23; H, 4.39; O, 29.41\%.

2-Hydroxy-3-(2-oxo-2-phenylethyl)naphthalene-1,4-dione (7): Yield (75\%); faint yellow powder; crystallized from benzene; m.p. $180^{\circ} \mathrm{C}$; IR (KBr): $v / \mathrm{cm}^{-1}=3343(\mathrm{OH}), 1781,1671,1646(\mathrm{C}=\mathrm{O}) ;{ }^{1} \mathrm{H}-\mathrm{NMR}$ $\left(300 \mathrm{MHz}, \mathrm{DMSO}-d_{6}\right) \delta(\mathrm{ppm})=6.1\left(\mathrm{~s}, 2 \mathrm{H}, \mathrm{CH}_{2}\right), 7.5-8.01(\mathrm{~m}, 9 \mathrm{H}, \mathrm{Ar}-$ $\mathrm{H}), 11.6(\mathrm{~s}, 1 \mathrm{H}, \mathrm{OH}) ;{ }^{13} \mathrm{C}-\mathrm{NMR}\left(75 \mathrm{MHz}, \mathrm{DMSO}-d_{6}\right) \delta(\mathrm{ppm})=176.8$, $175.1,166.7,165,149.8,115.8,133.2-130.8,28.2$; MS (EI, 70 ev) $\mathrm{m} / z(\%)$ $=292\left(\mathrm{M}^{+}, 3.5\right), 274(26.7), 185(12.4), 104(40), 77$ (100.0). Anal. Calcd. for $\mathrm{C} 18 \mathrm{H} 12 \mathrm{O} 4$ (292.28): C, 73.92; H, 4.14; O, 21.88\%. Found: C, 73.87; $\mathrm{H}, 4.19 ; \mathrm{O}, 21.82 \%$.

Reaction of ethyl 2-(3-hydroxy-1,4-dioxo-1,4-dihydronaphthalen-2-yl)-3- oxobutanoate (5) with hydrazine derivatives

General procedure: A mixture of $5(5 \mathrm{mmol})$ and hydrazine hydrate $(5 \mathrm{mmol})$ or phenyl hydrazine $(5 \mathrm{mmol})$ in ethanol $(25 \mathrm{~mL})$ containing catalytic amount of acetic acid was refluxed for 1-2 $\mathrm{h}$. The reaction mixture was then left to cool at room temperature. The formed precipitate was collected by filtration, dried and recrystallized from ethanol to give compounds 8 or 9 , respectively.

Ethyl 3-methyl-5,6-dioxo-1,4,5,6-tetrahydrobenzo[h]cinnoline-4- carboxylate (8): Yield (73\%); brown crystals; m.p. above $300^{\circ} \mathrm{C}$; IR (KBr): $v / \mathrm{cm}^{-1}=3442(\mathrm{NH}), 2972(\mathrm{CH}$, aliphatic), 1670, $1615(\mathrm{C}=\mathrm{O})$; ${ }^{1} \mathrm{H}-\mathrm{NMR}\left(300 \mathrm{MHz}, \mathrm{DMSO}-d_{6}\right) \delta(\mathrm{ppm})=1.4\left(\mathrm{t}, 3 \mathrm{H}, \mathrm{CH}_{2}-\mathrm{CH}_{3}\right), 2.04$ (s, 3H, $\left.\mathrm{CH}_{3}\right), 2.4(\mathrm{~s}, 1 \mathrm{H}, \mathrm{CH}), 4.2\left(\mathrm{q}, 2 \mathrm{H}, \mathrm{CH}_{2}\right), 7.5-8.3(\mathrm{~m}, 4 \mathrm{H}, \mathrm{Ar}-$ $\mathrm{H}), 10.8(\mathrm{~s}, 1 \mathrm{H}, \mathrm{NH}) ;{ }^{13} \mathrm{C}-\mathrm{NMR}\left(75 \mathrm{MHz}, \mathrm{DMSO}-d_{6}\right) \delta(\mathrm{ppm})=178.3$, $149.5,138.4,135.5,133.1,132.8,130.1,118.8,65.1,31.4,18.0,16.2$; MS (EI, $70 \mathrm{ev}) \mathrm{m} / z(\%)=298\left(\mathrm{M}^{+}, 0.4\right), 276$ (94.20), 248 (71.0), 219 (9.7), 192 (14.8), 163 (100.0), 138 (20.3). Anal. Calcd. for $\mathrm{C}_{16} \mathrm{H}_{14} \mathrm{~N}_{2} \mathrm{O}_{4}$ (298.30): C, 64.42; H, 4.73; N, 9.39; O, 21.95\%. Found: C, 64.48; H, 4.68; N, 9.30; O, 21.88\%.

Ethyl 3-methyl-5,6-dioxo-1-phenyl-1,4,5,6-tetrahydrobenzo[h] cinnoline-4-carboxylate (9): Yield (85\%); yellow needles; m.p. 230$3^{\circ} \mathrm{C}$; IR (KBr): $v / \mathrm{cm}^{-1}=2975(\mathrm{CH}$, aliphatic), 1738, 1671, $1614(\mathrm{C}=\mathrm{O})$;
${ }^{1} \mathrm{H}-\mathrm{NMR}\left(300 \mathrm{MHz}, \mathrm{DMSO}-d_{6}\right) \delta(\mathrm{ppm})=1.4\left(\mathrm{t}, 3 \mathrm{H}, \mathrm{CH}_{2}-\mathrm{CH}_{3}\right), 2.06$ (s, $1 \mathrm{H}, \mathrm{CH}), 2.5\left(\mathrm{~s}, 3 \mathrm{H}, \mathrm{CH}_{3}\right), 4.3\left(\mathrm{q}, 2 \mathrm{H}, \mathrm{CH}_{2}\right), 7.5-8.3(\mathrm{~m}, 9 \mathrm{H}, \mathrm{Ar}-$ $\mathrm{H}) ;{ }^{13} \mathrm{C}-\mathrm{NMR}\left(75 \mathrm{MHz}\right.$, DMSO- $\left.d_{6}\right) \delta(\mathrm{ppm})=182.8,180,168.4,155.8$, $144.2,136.2,129.4,127.1,124.3,122.0,121.7,114.5,112.3,66.5,33.7$, 18.4, 12.8; MS (EI, 70 ev) $\mathrm{m} / z(\%)=374\left(\mathrm{M}^{+}, 1.1\right), 352(100), 324$ (63.3), 295 (10.19), 77 (65). Anal. Calcd. for $\mathrm{C}_{22} \mathrm{H}_{18} \mathrm{~N}_{2} \mathrm{O}_{4}$ (374.39): C, 70.53; H, 4.87; N, 7.48; O, 17.09\%. Found: C, 70.48; H, 4.81; N, 7.40; O, 17.12\%.

Synthesis of (E)-2-(2-(3-hydroxy-1,4-dioxo-1,4-dihydronaphthalen-2-yl)-1-phenylethylidene)hydrazinecarbothioamide (10): A mixture of 7 ( $1.46 \mathrm{~g}, 5 \mathrm{mmol})$ and thiosemicarbazide $(5 \mathrm{mmol})$ in ethanol $(30 \mathrm{~mL})$ in the presence of acetic acid $(0.1 \mathrm{~mL})$ were heated under reflux for $2 \mathrm{~h}$ then left to cool. The resulting solid was filtered off and recrystallized from ethanol to give compound 10 . Yield (60\%); yellow crystals; m.p. $222-3^{\circ} \mathrm{C}$; IR $(\mathrm{KBr}): v / \mathrm{cm}^{-1}=3415\left(\mathrm{OH}, \mathrm{NH}, \mathrm{NH}_{2}\right), 1629$ $(\mathrm{C}=\mathrm{O}) ;{ }^{1} \mathrm{H}-\mathrm{NMR}\left(300 \mathrm{MHz}, \mathrm{DMSO}-d_{6}\right) \delta(\mathrm{ppm})=2.3\left(\mathrm{~s}, 1 \mathrm{H}, \mathrm{CH}_{2}\right)$, 6.07 (s, 1H, NH), 6.7-8.8 (m, 10H, Ar- H), 9.1 (s, 2H, NH2), 9.8 (s, $1 \mathrm{H}, \mathrm{NH}), 13.2(\mathrm{~s}, 1 \mathrm{H}, \mathrm{OH}) ;{ }^{13} \mathrm{C}-\mathrm{NMR}\left(75 \mathrm{MHz}, \mathrm{DMSO}-d_{6}\right) \delta(\mathrm{ppm})=$ 188.2, 184.8, 172.9, 175.3, 159.7, 158.3, 155, 138.2,135.4, 130.9, 129.5, $124.1,123,10.4$; MS (EI, $70 \mathrm{ev}) \mathrm{m} / z(\%)=365\left(\mathrm{M}^{+}, 6.39\right), 362(33.2), 149$ (100.0), 104 (24.5), 91 (91.1). Anal. Calcd. for $\mathrm{C}_{19} \mathrm{H}_{15} \mathrm{~N}_{3} \mathrm{O}_{3} \mathrm{~S}$ (365.41): C, 62.54; H, 4.14; N, 11.50; O, 13.14; S, 8.78\%. Found: C, 62.51; H, 4.19; N, $11.55 ; \mathrm{O}, 13.10 ; \mathrm{S}, 8.72 \%$.

Synthesis of 2-hydroxy-3-(2-phenyl-1H-indol-3-yl)naphthalene1,4-dione(11): A mixture of 3-phenacyl-1,4-naphthoquinone 7 (1.46 g, $5 \mathrm{mmol})$ and phenyl hydrazine $(5 \mathrm{mmol})$ in ethanol $(25 \mathrm{~mL})$ in presence of catalytic amount of acetic acid was refluxed for $2 \mathrm{~h}$ then left to cool. The precipitate formed was collected by filtration and recrystallized from ethanol to give compound 11. Yield (88\%); yellow crystals; m.p. 266- $8^{\circ} \mathrm{C}$; IR (KBr): $v / \mathrm{cm}^{-1}=3326(\mathrm{OH}), 1641,1614(\mathrm{C}=\mathrm{O}) ;{ }^{1} \mathrm{H}-\mathrm{NMR}$ $\left(300 \mathrm{MHz}, \mathrm{DMSO}-d_{6}\right) \delta(\mathrm{ppm})=6.07(\mathrm{~s}, 1 \mathrm{H}, \mathrm{NH}), 7.1-8.3(\mathrm{~m}, 13 \mathrm{H}, \mathrm{Ar}-$ $\mathrm{H}), 16.1(\mathrm{~s}, 1 \mathrm{H}, \mathrm{OH}) ;{ }^{13} \mathrm{C}-\mathrm{NMR}\left(75 \mathrm{MHz}, \mathrm{DMSO}-d_{6}\right) \delta(\mathrm{ppm})=189.1$, $183.2,176.4,155.6,149.2-123.3,110.2$; MS (EI, 70 ev) $\mathrm{m} / z(\%)=366$ $\left(\mathrm{M}^{+}, 1.5\right), 264$ (21.4), 130 (42.9), 115 (9.1), 102 (36), 77 (100.0). Anal. Calcd. for $\mathrm{C}_{22} \mathrm{H}_{18} \mathrm{~N}_{2} \mathrm{O}_{4}$ (365.38): C, 78.89; $\mathrm{H}, 4.14 ; \mathrm{N}, 3.83 ; \mathrm{O}, 13.14 \%$. Found: C, 78.83; H, 4.10; N, 3.78; O, 13.20\%.

Synthesis of ethyl 2-amino-5-(3-hydroxy-1,4-dioxo-1,4-dihydronaphthalen-2-yl)-4-phenylthiophene-3-carboxylate (12): A mixture of sulfur $(0.16 \mathrm{~g}, 5 \mathrm{mmol}), 7$ ( $1.46 \mathrm{~g}, 5 \mathrm{mmol})$, ethyl cyanoacetate $(0.57$ g, $5 \mathrm{mmol})$ in ethanol $(25 \mathrm{~mL})$ and morpholine $(0.44 \mathrm{~g}, 5 \mathrm{mmol})$ was added dropwise at $45^{\circ} \mathrm{C}$ over $15 \mathrm{~min}$. The reaction mixture was stirred for further $5 \mathrm{~h}$ at $80^{\circ} \mathrm{C}$ and then stirring $24 \mathrm{~h}$ at room temperature. Un-reacted sulfur was removed by filtration, and the filtrate was evaporated under reduced pressure. Purification of the crude product by silica gel column chromatography was obtained by silica gel column chromatography (pet.ether and ethyl acetate 5:2) afforded compound 12. Yield (43\%); as brown crystals; m.p. $216^{\circ} \mathrm{C}$; IR $(\mathrm{KBr}): v / \mathrm{cm}^{-1}=$ 3478, $3373\left(\mathrm{NH}_{2}\right), 3260(\mathrm{OH}), 1675,1606(\mathrm{C}=\mathrm{O}) ;{ }^{1} \mathrm{H}-\mathrm{NMR}(300 \mathrm{MHz}$, DMSO- $\left.d_{6}\right) \delta(\mathrm{ppm})=1.2\left(\mathrm{t}, 3 \mathrm{H}, \mathrm{CH}_{3}\right), 4.1\left(\mathrm{q}, 2 \mathrm{H}, \mathrm{CH}_{2}\right), 9.6(\mathrm{~s}, 1 \mathrm{H}$, $\mathrm{OH}), \delta$ 7.1-8.8 (m, 9H, Ar-H), $12.1\left(\mathrm{~s}, 2 \mathrm{H}, \mathrm{NH}_{2}\right) ;{ }^{13} \mathrm{C}-\mathrm{NMR}(75 \mathrm{MHz}$, DMSO- $\left.d_{6}\right) \delta(\mathrm{ppm})=189.1,177.5,159.1,148.1,144.1,140.6,139.3$, 133.4, 131.4, 129.9, 126.3, 120.2, 119.5, 116.3, 52.3, 19.5, 15.0 ; MS (EI, $70 \mathrm{ev}) \mathrm{m} / z(\%)=418\left(\mathrm{M}^{+}-1,55.7\right), 403$ (57.3), 342 (100.0), 270 (55.7), 252 (95.6), 246 (61.7), 155 (61.7), 95 (20.2). Anal. Calcd. for $\mathrm{C}_{23} \mathrm{H}_{17} \mathrm{NO}_{5} \mathrm{~S}$ (419.45): C, 65.86; H, 4.09; N, 3.34; O, 19.07; S, 7.64\%. Found: C, 65.81; $\mathrm{H}, 4.16 ; \mathrm{N}, 3.28 ; \mathrm{O}, 19.11 ; \mathrm{S}, 7.60 \%$.

Synthesis of 2-phenylnaphtho[2,3-b]furan-4,9-dione (13): Method A: A solution of $7(1.46 \mathrm{~g}, 5 \mathrm{mmol})$ in acetic acid $(25 \mathrm{~mL})$ containing sodium acetate $(25 \mathrm{mmol})$ was refluxed for $6 \mathrm{~h}$. The reaction mixture was left to cool at room temperature and then poured into ice- 
water. The formed precipitate was collected by filtration, dried and recrystallized from benzene to give compound 13.

Method B: A mixture of 1,4-naphthoquinone (15) $(5 \mathrm{mmol})$ in acetonitrile $(5 \mathrm{~mL})$ was added dropwise during an interval $15 \mathrm{~min}$ with stirring to a mixture of $14(5 \mathrm{mmol})$ in acetonitrile $(25 \mathrm{~mL})$ containing triethylamine $(0.5 \mathrm{~mL})$. The reaction mixture was stirred at room temperature for $7 \mathrm{~h}$. The solvent was evaporated in vacuum to its half volume. The precipitated solid was filtered off, dried and recrystallized with benzene to give compound 13 . Yield (A, 75; B, 82\%); buff crystals; m.p. $235^{\circ} \mathrm{C}$; IR $(\mathrm{KBr}): v / \mathrm{cm}^{-1}=3055(\mathrm{CH}$, aromatic), 1675, $1639(\mathrm{C}=\mathrm{O})$; ${ }^{1} \mathrm{H}-\mathrm{NMR}\left(300 \mathrm{MHz}, \mathrm{DMSO}-d_{6}\right) \delta(\mathrm{ppm})=7.4-8.1(\mathrm{~m}, 10 \mathrm{H}, \mathrm{Ar}-\mathrm{H})$; ${ }^{13} \mathrm{C}-\mathrm{NMR}\left(75 \mathrm{MHz}\right.$, DMSO- $\left.d_{6}\right) \delta(\mathrm{ppm})=182.3,158.2,145.8,136.9$, $134,133,128.3,126.4,120.1,119.7,111.5,105.3$; MS (EI, 70 ev) $\mathrm{m} / z$ $(\%)=274\left(\mathrm{M}^{+}, 8.2\right), 129(9.6), 105(9.6), 86(100.0)$. Anal. Calcd. for $\mathrm{C}_{18} \mathrm{H}_{10} \mathrm{O}_{3}$ (274.27): C, 78.82; H, 3.67; O, 17.50\%. Found: C, 78.79; H, $3.62 ; \mathrm{O}, 17.45 \%$.

Synthesis of 4,9-dioxo-2-phenyl-4,9-dihydronaphtho[2,3-b] furan-3- carbaldehyde (16): To a solution of $13(1.6 \mathrm{~g}, 6 \mathrm{mmol})$ in anhydrous DMF $(10 \mathrm{~mL})$, phosphorus oxychloride $(1 \mathrm{~mL})$ was added slowly with vigorous stirring. The reaction mixture was stirred at $0-5^{\circ} \mathrm{C}$ for further $30 \mathrm{~min}$ followed by stirring under reflux on water bath for 2 $h$. The reaction mixture was left to cool then ice was added and sodium acetate solution until the $\mathrm{pH}$ 7. The precipitated solid was filtered off, washed with water, dried and recrystallized from a mixture of DMF /ethanol (1:1) to give compound 16. Yield (50\%); reddish brown crystals; m.p. above $300^{\circ} \mathrm{C}$; IR $(\mathrm{KBr}): v / \mathrm{cm}^{-1}=3056(\mathrm{CH}$, aldehydic), 1643, $1622(\mathrm{C}=\mathrm{O}) ;{ }^{1} \mathrm{H}-\mathrm{NMR}\left(300 \mathrm{MHz}, \mathrm{DMSO}-d_{6}\right) \delta(\mathrm{ppm})=9.4(\mathrm{~s}$, $1 \mathrm{H}, \mathrm{CHO}), 6.7-7.6(\mathrm{~m}, 9 \mathrm{H}, \mathrm{Ar}-\mathrm{H}) ;{ }^{13} \mathrm{C}-\mathrm{NMR}\left(75 \mathrm{MHz}, \mathrm{DMSO}-d_{6}\right)$ $\delta(\mathrm{ppm})=183.2,180.4,175.8,158.2,150.7,140-128$; MS (EI, $70 \mathrm{ev})$ $\mathrm{m} / z(\%)=300\left(\mathrm{M}^{+}-2,13\right), 251(14), 197(17), 172(15), 156(14), 143$ (18), 104 (23), 83 (100.0), 77 (55). Anal. Calcd. for $\mathrm{C}_{19} \mathrm{H}_{10} \mathrm{O}_{4}$ (302.27): C, 75.49; H, 3.33; O, 21.17\%. Found: C, 75.54; H, 3.28; O, 21.21\%.

Synthesis of (E)-3-((4-nitrophenyl)diazenyl)-2-phenylnaphtho[2,3- b] furan-4,9-dione (17): To a well-stirred cooled solution of p-nitroaniline $(5 \mathrm{mmol})$ in concentrated $\mathrm{HCl}(1 \mathrm{~mL})$, a solution of $\mathrm{NaNO}_{2}\left(5 \mathrm{mmol}\right.$ in $\left.2 \mathrm{~mL} \mathrm{H}_{2} \mathrm{O}\right)$ was added drop wise. The above cooled diazonium solution was added slowly to a well-stirred solution of 13 (5 mmol) in pyridine $(15 \mathrm{~mL})$. The reaction mixture was stirred for $2 \mathrm{~h}$. The crude product was filtered off, dried well and recrystallized from a mixture of DMF/ ethanol to afford compound 17. Yield (48\%); reddish brown powder; m.p. $178^{\circ} \mathrm{C}$; IR $(\mathrm{KBr}): v / \mathrm{cm}^{-1}=1666,1592(\mathrm{C}=\mathrm{O})$, $1549(\mathrm{~N}=\mathrm{N}) .{ }^{1} \mathrm{H}-\mathrm{NMR}\left(300 \mathrm{MHz}, \mathrm{DMSO}-d_{6}\right) \delta(\mathrm{ppm})=7.1-7.9(\mathrm{~m}$, $23 \mathrm{H}, \mathrm{Ar}-\mathrm{H}) ;{ }^{13} \mathrm{C}-\mathrm{NMR}\left(75 \mathrm{MHz}, \mathrm{DMSO}-d_{6}\right) \delta(\mathrm{ppm})=188.3,182,179$, 175.2, 155-132(m), 121.7, 118.4; MS (EI, $70 \mathrm{ev)} \mathrm{m} / z(\%)=425\left(\mathrm{M}^{+}+2\right.$, 33.1), 375 (31), 209 (31.8), 130 (30), 122 (37), 105 (12.3). Anal. Calcd. for $\mathrm{C}_{23} \mathrm{H}_{17} \mathrm{NO}_{5} \mathrm{~S}$ (423.38): C, 68.09; $\mathrm{H}, 3.09 ; \mathrm{N}, 9.92 ; \mathrm{O}, 18.89 \%$. Found: C, 68.18; H, 3.02; N, 9.97; O, $18.80 \%$.

Synthesis of 2-(4-(4-chlorophenyl)-2,6-diphenylpyridin-3-yl)-3hydroxynaphthalene-1,4-dione (18): A mixture of 7 (1.46 g, $5 \mathrm{mmol}$ ), $\mathrm{N}$-phenacylpyridinium iodide $(5.2 \mathrm{mmol})$ and $p$-chlorobenzaldhyde $(5 \mathrm{mmol})$ in acetic acid containing ammonium acetate $(5 \mathrm{mmol})$ was refluxed for $5 \mathrm{~h}$. The mixture was left to cool and the obtained solid product was filtered off, dried and recrystallized from acetic acid to give 18. Yield (85\%); reddish brown needles; m.p. $274^{\circ} \mathrm{C}$; IR $(\mathrm{KBr}): v / \mathrm{cm}$ ${ }^{1}=3374(\mathrm{OH}), 1681,1640(\mathrm{C}=\mathrm{O}) ;{ }^{1} \mathrm{H}-\mathrm{NMR}\left(300 \mathrm{MHz}, \mathrm{DMSO}-d_{6}\right) \delta$ $(\mathrm{ppm})=5.4(\mathrm{~s}, 1 \mathrm{H}, \mathrm{OH}), 7.2-8.4(\mathrm{~m}, 19 \mathrm{H}, \mathrm{Ar}-\mathrm{H}) ;{ }^{13} \mathrm{C}-\mathrm{NMR}(75 \mathrm{MHz}$, DMSO- $\left.d_{6}\right) \delta(\mathrm{ppm})=188.0,180.1,172.4,158.9,149.5,144.7,138$, $128.1-132.3,122.3,119.6,115.5,110.2$; MS (EI, $70 \mathrm{ev)} \mathrm{m} / z(\%)=513$ $\left(\mathrm{M}^{+}, 42\right), 478$ (41), 402 (43), 340 (100.0), 157 (35), 131 (11), 110 (52),
104 (29), 77 (53). Anal. Calcd. for $\mathrm{C}_{43} \mathrm{H}_{23} \mathrm{~N}_{3} \mathrm{O}_{9}$ (513.97): C, 77.12; $\mathrm{H}$, 3.92; N, 2.73; O, 9.34 Found: C, 77.17; H, 3.87; N, 2.78; O, 9.33\%.

Reaction of 2-hydroxy-3-(2-oxo-2-phenylethyl)naphthalene-1,4dione (7)with arylidenemalononitrile: A solution of $7(0.01 \mathrm{~mol})$ and $19(0.01 \mathrm{~mol})$ in ethanol $(30 \mathrm{~mL})$ containing triethylamine $(0.3 \mathrm{~mL})$ was refluxed for $3 \mathrm{~h}$ at $60^{\circ} \mathrm{C}$. The reaction mixture was left to stand at $20^{\circ} \mathrm{C}$ for $24 \mathrm{~h}$. The precipitated solid was filtered off, washed with ethanol and recrystallized from ethanol to give compound 20. The filtrate was evaporated in vacuum and the obtained solid product was filtered off, dried and recrystallized from ethyl acetate to give compound 21.

2-Amino-5-(3-hydroxy-1,4-dioxo-1,4-dihydronaphthalen-2yl)-4-(4-methoxyphenyl)-6-phenyl-4H-pyran-3-carbonitrile (20): Yield (32\%); brown powder; m.p. $215^{\circ} \mathrm{C}$; IR $(\mathrm{KBr}): v / \mathrm{cm}^{-1}=3220,3403$ (NH2),2927 (CH, aliphatic), $2220(\mathrm{CN}), 1660,1596(\mathrm{C}=\mathrm{O}) ;{ }^{1} \mathrm{H}-\mathrm{NMR}$ $\left(300 \mathrm{MHz}, \mathrm{DMSO}-d_{6}\right) \delta(\mathrm{ppm})=3.6(\mathrm{~s}, 3 \mathrm{H}, \mathrm{CH} 3), 3.8(\mathrm{~s}, 1 \mathrm{H}, \mathrm{CH}), 4.5$ (s, 2H, NH2), 6.7-7.9 (m, 9H, Ar-H); ${ }^{13} \mathrm{C}-\mathrm{NMR}$ (75 MHz, DMSO- $d_{6}$ ) $\delta(\mathrm{ppm})=173.2,159.1,155.3,149.5,130.5-139.8,128.9,125.2,120$, $118.9,112,102.4,65,60.3,52.4,45.6,41.1 ;$ MS (EI, 70 ev) $\mathrm{m} / z(\%)=476$ $\left(\mathrm{M}^{+}, 0.7\right), 340$ (100.0), 111 (7.8), 105 (56.5), 77 (11.2). Anal. Calcd. for $\mathrm{C}_{29} \mathrm{H}_{20} \mathrm{~N}_{2} \mathrm{O}_{5}$ (476.48): C, 73.10; H, 4.23; N, 5.88; O, 16.79\%. Found: C, 73.15; H, 4.19; N, 5.81; O, 16.73\%.

2-(2-(3-Hydroxy-1,4-dioxo-1,4-dihydronaphthalen-2-yl)-1-(4methoxy- phenyl)-3-oxo-3-phenylpropyl)malononitrile (21): Yield (68\%); yellow powder; m.p. $123-4^{\circ} \mathrm{C}$; IR $(\mathrm{KBr}): v / \mathrm{cm}^{-1}=3340(\mathrm{OH})$, 2931 (CH, aliphatic), $2210(\mathrm{CN}), 1666,1602(\mathrm{C}=\mathrm{O})$; ${ }^{1} \mathrm{H}-\mathrm{NMR}(300$ $\left.\mathrm{MHz}, \mathrm{DMSO}-d_{6}\right) \delta(\mathrm{ppm})=2.9(\mathrm{~d}, 1 \mathrm{H}, \mathrm{CH}-\mathrm{CN}), 3.7(\mathrm{~s}, 3 \mathrm{H}, \mathrm{OCH} 3), 6.1$ $(\mathrm{s}, 1 \mathrm{H}, \mathrm{OH}), 4.6(\mathrm{~d}, 1 \mathrm{H}, \mathrm{CHCO}), 3.9(\mathrm{t}, 1 \mathrm{H}, \mathrm{CH}-\mathrm{Ar}), 6.7-8.0(\mathrm{~m}, 13 \mathrm{H}$, $\mathrm{H}-\mathrm{Ar}) ;{ }^{13} \mathrm{C}-\mathrm{NMR}\left(75 \mathrm{MHz}, \mathrm{DMSO}-d_{6}\right) \delta(\mathrm{ppm})=199.3,174.8,166.8$, 155.1, 139.7, 136.8, 130.2, 128.9, 126.1, 122.4, 110.9-120.6, 39.9, 30.3, 21.1; MS (EI, $70 \mathrm{ev}) \mathrm{m} / z(\%)=476\left(\mathrm{M}^{+}, 13.4\right), 369$ (9.05), 263 (27.5), 233 (16.2), 184 (46.4), 174 (57.4), 104 (53), 76 (100.0). Anal. Calcd. for $\mathrm{C}_{29} \mathrm{H}_{20} \mathrm{~N}_{2} \mathrm{O}_{5}$ (476.48): C, 73.10; H, 4.23; N, 5.88; O, 16.79\%. Found: C, 73.05; H, 4.29; N, 5.80; O, 16.73\%.

Synthesis of 2-(2-(4-chlorophenyl)-4-phenyl-2,10adihydro-1H- benzo[4,5] thiazolo[3,2-a]pyrimidin-3-yl)-3-hydroxynaphthalene-1,4-dione (23): A mixture of 2-aminobenzo $[d]$ thiazole $(5 \mathrm{mmol}), 7(5 \mathrm{mmol})$ and $p$-chlorobenzaldehyde $(5 \mathrm{mmol})$ in DMF ( $2 \mathrm{~mL}$ ) was refluxed for $10 \mathrm{~min}$ until the solid product was obtained. The mixture was left to cool and 2-propanol $(10 \mathrm{~mL})$ was added. The precipitated solid was filtered off, dried and recrystallized from ethanol to give compound 23. Yield (71\%); brown crystals; m.p. $160^{\circ} \mathrm{C}$; IR $(\mathrm{KBr}): v / \mathrm{cm}^{-1}=3442(\mathrm{OH}), 3417(\mathrm{NH}), 2923(\mathrm{CH}$, aliphatic), 1668, $1621(\mathrm{C}=\mathrm{O})$; ${ }^{1} \mathrm{H}-\mathrm{NMR}\left(300 \mathrm{MHz}, \mathrm{DMSO}-d_{6}\right) \delta(\mathrm{ppm})=2.7(\mathrm{~s}$, $1 \mathrm{H}, \mathrm{CH}), 2.9$ (s, 1H,CHS), $5.2(\mathrm{~s}, 1 \mathrm{H}, \mathrm{NH}), 6.8(\mathrm{~s}, 1 \mathrm{H}, \mathrm{OH}), 7.3-7.9$ $(\mathrm{m}, 17 \mathrm{H}, \mathrm{Ar}-\mathrm{H}) ;{ }^{13} \mathrm{C}-\mathrm{NMR}\left(75 \mathrm{MHz}, \mathrm{DMSO}-d_{6}\right) \delta(\mathrm{ppm})=172.0,170.3$, 164.0, 155.0, 132.0, 152, 126, 122.8, 120.5, 119.0, 115.7, 110, 101.5, 68.4, 54.8; MS (EI, $70 \mathrm{ev}) m / z(\%)=546\left(\mathrm{M}^{+}-2,26\right), 360(26.8), 173(37.4)$, 148 (50.7), 107 (92), 77 (100.0). Anal. Calcd. For $\mathrm{C}_{43} \mathrm{H}_{23} \mathrm{~N}_{3} \mathrm{O}_{9}$ (548.04): C, $70.00 ; \mathrm{H}, 3.86 ; \mathrm{N}, 5.10 \%$. Found: C, 70.04; H, 3.80; N, 5.02\%.

\section{Scavenging effect of nitro blue tetrazolium (NBT)}

The antioxidant activity of the synthesized compounds was investigated and compared with that of well-known free radical scavengers such as (vitamin C). Superoxide radicals were generated by xanthine/xanthine oxidase (XO) and measured spectrophotometrically $(560 \mathrm{~nm})$ by nitro blue tetrazolium (NBT) [40] photoreduction method of McCord and Fridovich. 
The superoxide scavenging activity was calculated according to the following formula:

$$
\text { Superoxide scavengingactivity } \%=\frac{\mathrm{A}(\text { control })-\mathrm{A}(\text { sample })}{\mathrm{A}(\text { control })} \times 100
$$

Where Absorbance (control) and Absorbance (sample) represent an increase in absorbance in the absence and presence of the tested samples, respectively.

\section{Brine shrimp lethality assay}

The brine shrimp [41,42] eggs (Artemia salina) were hatched in artificial sea water and used after $48 \mathrm{~h}$, providing large numbers of larvae. These tiny shrimp larvae have been extensively used as a tool to monitor the cytotoxicity of samples under study. This is a rabid, inexpensive and general bioassay which has been developed for screening. It easily utilizes a large number of organisms for statistical validation and requires no special equipment and a relatively small amount of sample is sufficient. Furthermore, it does not require animal serum, as it is needed for determination of cytotoxicities.

Materials: Artemia Salina Leach (brine shrimp eggs), sea salt, sample tank with perforated diving dam and cover to grow the shrimps; lamp to attract shrimps, magnifying glass, Organic solvent (DMSO), distilled water, Pasteur pipettes, Aluminum foil, test samples (our synthetic compounds)

Methods: The lethality test assay was done as described previously [42] by dissolving the samples in dimethylsulfoxide (DMSO) at different concentrations $(1,0.1$ and $0.01 \mathrm{mg} / \mathrm{ml})$ in triplicate were transferred in glass vials and then evaporated. Then artificial sea water was added to each vial $(5 \mathrm{ml})$ to achieve the correct concentration.

Artificial sea water is prepared by dissolving ca.3.8 $\mathrm{g}$ sea salt per liter of water and filtered. Sea water is placed in a small unequally divided tank and shrimp eggs added to the larger compartment of the tank which is darkened by covering it with aluminum foil. The illuminated compartment attracts shrimp larvae (nauplii) though perforations in the dam. Then allowed to stand for two days at room temperature (22$29^{\circ} \mathrm{C}$ ) for the shrimps to hatch and mature.

Prepare vials for testing; for each fraction, test initially at 1000 , $100,10 \mu \mathrm{g} / \mathrm{ml}$; prepare 3 replicates for each concentration, making a total of 9 vials; weight $20 \mathrm{mg}$ of sample and add $2 \mathrm{~mL}$ of organic solvent (DMSO) $(20 \mathrm{mg} / 2 \mathrm{ml})$; from this solution transfer 500,50 or $5 \mu \mathrm{l}$ to vials corresponding to 1000,100 , or $10 \mu \mathrm{g} / \mathrm{ml}$, respectively. Evaporate solvent under nitrogen and then place under high vacuum for about $30 \mathrm{~min}$; the volatile organic solvents will evaporate overnight. Alternatively, polar insoluble materials may be dissolved in DMSO, and up to $50 \mu \mathrm{l}$ may be added per $5 \mathrm{ml}$ of sea water before DMSO toxic affects the results. After 2 days (while the brine shimp larvae have matured), add $5 \mathrm{ml}$ sea water to each vial and add 10 ships per vial with the help of a Pasteur pipette (30 shrimp per dilution). The vial is maintained under illumination. After 24 hours have elapsed, count and record the number of surviving shrimps, with the aid of a $3 \mathrm{x}$ magnifying glass. From this, the percentage of lethality of brine shrimp nipplii was calculated at each concentration for each sample.

\section{Conclusion}

The aim of the present study was to synthesize some novel naphthoquinone derivatives and evaluate them as antioxidant and cytotoxic activities. The data showed clearly that compounds 21 and 23 showed the highest antioxidant activity. Moreover compounds 3, 12, 18 and 23 exhibited high cytotoxic activity.

\section{References}

1. Smith JC (1984) Synthetically useful reactions of epoxides, Synthesis 8: 629656.

2. Shchukina LA, Khokhlov AS, Shemyakin MM (1951) Zhur Obshchei Khim 21: 908-917; C A 46 (1952) 958c

3. Marchand P, Dong EZ (1998) Tetrahedron 54: 4459-4470.

4. Valderrama JAO, Espinoza MF, Gonzalez RA, Tapia J, Rodriguez AC, et al. (2006) Tetrahedron 62: 2631-2638.

5. Shchukina LA, Vinogradova El, Shemyakin MM, Zhur, ObshcheiKhim, et al. (1952) Russ J Gen Chem 21: 1661-1667; C. A. 46 3990d.

6. Ichihara M, Kobayashi K, Oda S Sakamura (1978) Bull Chem Soc 51: 826-829

7. Silver RF, Holmes HL (1968) Synthesis of some 1,4-naphthoquinones and reactions relating to their use in the study of bacterial growth inhibition. Can $\mathrm{J}$ Chem 46: 1859-1864.

8. Akatsuka M, Yakugaku Zasshi (1973) 93: 1308-13; C. A. 80 (1974)27010s.

9. Wilgus S, Frauenglass E, Chiesa PP, Nawn GH, Evans FJ, et al. (1966) J Chem 44: 603-609.

10. Bobrov Ya, Zachinyaev Izv, Vyssh, Uchebn, Zaved, et al. (1993) Khim Khim Tekhnol 36: 25-28; A.120 (1994) 8446s.

11. Bobrov Ya, Zachinyaev V, Ukr Khim Zh (1996) 62: 50-53; C. A.126 (1997) 293332e.

12. Jeffery M, Yeh HJC, Jerina DM (1974) Synthesis of cis-1,2-dihydroxy-1,2dihydronaphthalene and cis-1,4-dihydroxy-1,4-dihydronaphthalene. J Org Chem 39: 1405-1407.

13. Maruyama K, Naruta $Y$ (1978) Chem Lett 431-432.

14. Choi Y, Oh C, Ham SW (2009) Bull Korean Chem Soc 30: 1697-1698.

15. Adeniyi BA, Robert MF, Chai H, Fong HH (2003) In vitro cytotoxicity activity of Diosquinone, a naphthoquinone epoxide. Phytother Res 17: 282-284.

16. Perry NB, Blunt JW, Munro MH (1991) A cytotoxic and antifungal 1,4-naphthoquinone and related compounds from a New Zealand brown algae, Landsburgia quercifolia. J Nat Prod 54: 978-985.

17. Wu CC, Peng CF, Tsai IL, Abd El-Razek MH, Huang HS, et al. (2007) Secondary metabolites from the roots of Engelhardia roxburghiana and thei antitubercular activities. Phytochemistry 68: 1338-1343.

18. Ball EG, Anfinsen CB, Cooper O (1947) The inhibitory action of naphthoquinones on respiratory processes. J Biol Chem 168: 257-270.

19. Mehendale R, Thomson RH (1975) Binaphthoquinones in Lomatia ferruginea. Phytochemistry 14: 801-802.

20. Yin J1, Liebeskind LS (1998) A Synthesis of Trisquinones. J Org Chem 63 5726-5727.

21. Powis G (1987) Metabolism and reactions of quinoid anticancer agents. Pharmacol Ther 35: 57-162.

22. Croft SL, Hogg J, Gutteridge WE, Hudson AT, Randall AW (1992) The activity of hydroxynaphthoquinones against Leishmania donovani. J Antimicrob Chemother 30: 827-832.

23. Munday R, Smith BL, Munday CM (1995) Comparative toxicity of 2-hydroxy-3alkyl-1,4-naphthoquinones in rats. Chem Biol Interact 98: 185-192.

24. Subramanian MMC, Ferreira M Trsic (1998) A Structure-Activity Relationship Study of Lapachol and Some Derivatives of 1,4-Naphthoquinones Against CarcinosarcomaWalker256. Struct. Chem 9: 47-57.

25. Goulart MOF, Zani CL, Tonholo J, Freitas LR, FC de Abreu (1997) Med Chem Lett 7: 2043-2048.

26. Santos AF, Ferraz PA, de Abreu FC, Chiari E, Goulart MO, et al. (2001) Molluscicidal and trypanocidal activities of lapachol derivatives. Planta Med 67: 92-93.

27. dos Santos AF, Ferraz PA, Pinto AV, Pinto M do C, Goulart MO, et al. (2000) Molluscicidal activity of 2-hydroxy-3-alkyl-1,4-naphthoquinones and derivatives. Int J Parasitol 30: 1199-1202.

28. Lima NM, dos Santos AF, PorfÃrio Z, Goulart MO, Sant'Ana AE (2002) Toxicity of lapachol and isolapachol and their potassium salts against Biomphalaria glabrata, Schistosoma mansoni cercariae, Artemia salina and Tilapia nilotica. Acta Trop 83: 43-47. 
Citation: Berghot MA, Kandeel EM, Abdel-Rahman AH, Abdel-Motaal M (2014) Synthesis, Antioxidant and Cytotoxic Activities of Novel Naphthoquinone Derivatives from 2,3-Dihydro-2,3-Epoxy-1,4- Naphthoquinone. Med chem 4: 381-388. doi:10.4172/2161-0444.1000169

29. B. Wendel (1946) Federation Proceedings 5: 406-407.

30. Lima NMF, Correia CS, Ferraz PAL, Pinto AV, Pinto MCRF, et al. (2002) Chem Soc 13: $822-829$

31. Parker KA, Sworin ME, Org J (1981) Chem 46: 3218-3223.

32. Bekaert, Andrieux J, Plat M, Brion J-D (1997) Tetrahedron Lett 38: 4219-4220.

33. Betts RL, Murphy ST, Johnson CR, (2004) Enzymatic desymmetrization/ resolution of epoxydiols derived from 1,4-naphthoquinone, 5-hydroxy1,4-naphthoquinone and 5,8-dihydroxy-1,4-naphthoquinone. Tetrahedron Asym.15: 2853-2860

34. Lee L, Villalba MM, Smith RB, Davis J (2009) Epoxide-quinone transformations: Multi-parametric indicators for assessing animal welfare. Electrochem Commun 11: $1555-1558$.

35. Yan CG, Cai XM, Wang QF, Wang TY, Zheng M (2007) Microwave-assisted four-component, one-pot condensation reaction: an efficient synthesis of annulated pyridines. Org Biomol Chem 5: 945-951.

36. Yan G, Wang QF, Cai XM, Sun J (2008) Cent Eur Chem 6: 188-198.
37. Krauze G, Duburs (2002) Chem Heterocycl Comp 38: 251-252.

38. Lee IK, Jung JY, Seok SJ, Kim WG, Yun BS (2006) Free radical scavengers from the medicinal mushroom Inonotus xeranticus and their proposed biogenesis. Bioorg Med Chem Lett 16: 5621-5624.

39. Athukorala Y, Kim KN, Jeon YJ (2006) Antiproliferative and antioxidant properties of an enzymatic hydrolysate from brown alga, Ecklonia cava. Food Chem Toxicol 44: 1065-1074.

40. Lee JY, Yoon JW, Kim CT, Lim ST (2004) Bioorg Med Chem Lett 65: 3033 3039.

41. Silva TM, Camara CA, Barbosa TP, Soares AZ, da Cunha LC, et al. (2005) Molluscicidal activity of synthetic lapachol amino and hydrogenated derivatives. Bioorg Med Chem 13: 193-196.

42. Barbosa TP, Camara CA, Silva TM, Martins RM, Pinto AC, et al. (2005) New 1,2,3,4-tetrahydro-1-aza-anthraquinones and 2-aminoalkyl compounds from norlapachol with molluscicidal activity. Bioorg Med Chem 13: 6464-6469. 